\title{
ISOLATION AND CHARACTERIZATION OF TWO IMMUNOLOGICALLY DISTINCT FORMS OF $\alpha$-AMYLASE AND A $\beta$-AMYLASE FROM SEEDS OF GERMINATED SORGHUM BICOLOR (L.) MOENCH
}

by

JOHN MUNDY

\author{
Department of Biotechnology, Carlsberg Research Laboratory, \\ Gamle Carlsberg Vej 10, DK-2500 Valby Copenhagen \\ and \\ Institute of Biochemical Genetics, Copenhagen University, \\ Øster Farimagsgade 2A, DK-1353, Copenhagen, Denmark
}

Keywords: Affinity chromatography, hydrophobic interaction, isoelectric focusing, multiple molecular forms, enzyme inhibition, monospecific antibodies

Two immunologically distinct forms of $\alpha$-amylase named $\alpha-1$ and $\alpha-2$ and a $\beta$-amylase were isolated from germinated sorghum by affinity-, hydroxylapatite- and hydrophobic interaction chromatography. The two $\alpha$-amylases showed similar molecular weights of $41,500-42,700$ as determined by electrophoresis and gel permeation chromatography. The two enzymes have similar amino acid compositions except for differences in Ser, Val, Ile, and Cys. They have slightly different isoelectric points of 4.65 for $\alpha-1$ (major form) and 5.1 for $\alpha-2$. $\alpha-1$ and $\alpha-2$ amylases contain $0.7 \%$ and $5.7 \%$ carbohydrate by weight respectively and they exhibit different kinetic properties and substrate specificities.

Crossed immunoelectrophoresis and immunodiffusion of sorghum $\alpha-1$ amylase against monospecific anti-barley $\alpha-2$ amylase showed immunological identity between barley malt $\alpha-2$ and sorghum malt $\alpha-1$ amylase. Non-identity was seen between sorghum $\alpha-2$ and the barley malt amylase. Sorghum $\alpha-1$ and $\alpha-2$ amylase show partial immunological identity. $\alpha-1$ amylase could only be detected in trace amounts in ungerminated sorghum.

\footnotetext{
Abbreviations:

$\mathrm{CHpA}=$ cycloheptaamylose $; \mathrm{EDTA}=$ Ethylenediamine-tetraacetate-disodium salt; $\mathrm{IEF}=$ isoelectric focusing; IgG = immunoglobulin G; = SDS-PAGE sodium dodecyl-sulfate polyacrylamide gel electrophoresis.
} 


\section{INTRODUCTION}

Multiple forms of amylase have been detected in a number of cereals $(5,12,19,25,30)$ and several studies have suggested that these forms are the result of ontogenic and/or tissue specific differential gene expression $(8,27)$. Genetic and biochemical studies $(12,19)$ of amylases in barley have established the existence of two forms of $\alpha$ amylase, now generally referred to as $\alpha-1$ (green) and $\alpha-2$ (malt) amylase. Similar work with maize revealed the existence of two $\alpha$-isozymes controlled by co-dominant alleles (5).

Studies on the histological development of amylases during cereal germination have shown that $\beta$-amylase is synthesized during seed development (14). The de novo synthesis of $\alpha$ amylase by barley aleurone layers is well documented (6) and work on this system has elucidated the level of molecular control of protein synthesis by gibberellic and abscisic acids (21). Recent work has also shown that the scutellum is important in hydrolase production during the early stages of germination in rice (24) and barley (13).

Active $\alpha$-amylases produced during the germination of sorghum are both soluble and insoluble. An early study by Novellie (23) suggested that insoluble sorghum $\alpha$-amylase can be released during extraction by desorption from the surface of an insoluble protein. A later study of DaIBER (7) showed that soluble $\alpha$-amylase is inhibited by endogenous polyphenols during extraction.

The present study was undertaken to 1 ) determine if multiple forms of $\alpha$-amylase exist in malted sorghum, 2) to characterize the possibly existing forms and 3) to produce monospecific rabbit antibodies against amylases present in germinated sorghum for subsequent immunohistological studies.

\section{MATERIALS AND METHODS}

\subsection{Plant material}

Seeds of Sorghum bicolor (L.) Moench (cv. Dabar) a white, low-tannin, testa-less Sudanese variety were kindly supplied by Dr. S. BADI, Food Research Center, Khartoum, Sudan. Sorghum green malt was prepared by steeping seed for 24 hours at $30^{\circ} \mathrm{C}$ with two I hour aerations, followed by a five day germination in a rotating- drum laboratory unit at $28{ }^{\circ} \mathrm{C}-30^{\circ} \mathrm{C}$ and 80 $90 \%$ relative humidity.

\subsection{Chemicals}

Sephadex G-75 superfine and LH-20, epoxyactivated Sepharose 6B, Octyl-Sepharose CL4B, DEAE-Sephadex A50, Phadebas blue starch tablets and low molecular weight size standards were from Pharmacia, Uppsala, Sweden. Biogel P100 and Biogel HTP were from Biorad Labs. Richmond, California, USA. Cycloheptaamylose (Schardinger $\beta$-cyclodextrin, $\mathrm{CHpA}$ ) and oyster glycogen were from Sigma Chemical Co., St. Louis, Missouri, USA. Carrier ampholytes 4-6 were obtained from LKB, Bromma, Sweden. $\beta$-limit dextrin was from $\mathrm{BDH}$ Chemicals, Poole, England. Soluble starch and TLC silica gel 60 aluminum sheets were from Merck, Darmstadt, Germany. Pullulan was a kind gift from lic. techn. B. EnEvoldsen, Carlsberg Research Laboratory, Copenhagen, Denmark. Monospecific anti-barley $\alpha-2$ amylase and anti-barley $\beta$-amylase were a gift of Dr. G. GiBBONS, Carlsberg Research Laboratory. All purchased chemicals were of reagent grade and were used without further purification.

\subsection{Electrophoretic techniques}

Immunoelectrophoresis and isoelectric focusing in polyacrylamide gel (IEF-PAGE) were run as previously described ( $\mathrm{l}$ and 34 ) with $1 \mathrm{mM}$ $\mathrm{CaCl}_{2}$ incorporated in the gels. Sodium dodecyl sulfate polyacryalmide gel electrophoresis (SDSPAGE) was performed after Neville (22) using a $12.5 \%$ gel. Total malt extracts for SDS-PAGE were precipitated with $5 \%$ trichloroacetic acid for $30 \mathrm{~min}$ on ice prior to reduction. Serine protease activity was inhibited by including $10 \mathrm{~mm}$-EDTA or $500 \mu \mathrm{M}$-phenyl-methyl-sulfonyl chloride or $\mathrm{n}$ $\alpha$-p tosyl-L-Lysine in the extraction buffer.

\subsection{Measurement of amylase activity}

Amylolytic activity was localized in immunoand IEF-gels as described by HeJGAARD (14) using $2 \% \beta$-limit dextrin in $50 \mathrm{~mm}$-Na-acetate buffer, pH 5.5, $1 \mathrm{mM}-\mathrm{CaCl}_{2}$ for specific detection of $\alpha$-amylase.

Amylolytic activity in chromatographic column fractions was routinely monitored with Phadebas blue starch tablets. 
Activity measurements for kinetic analysis were performed using either the dinitro-salicylic acid reducing sugar test (33) or with the neocuproin reagent described by DYGERT et al. (10).

Hydrolysis products released by the enzymes from $1 \%$ soluble starch were examined on thin layer silica gel plates developed once in butanolformic acid-water (33:50:17) after KoLLER AND NeUKON (17), sprayed with $5 \% \mathrm{H}_{2} \mathrm{SO}_{4}$ in ethanol and developed by heating at $110^{\circ} \mathrm{C}$ for $10 \mathrm{~min}$.

\subsection{Amino acid analysis and carbohydrate content of purified proteins}

Amino acid compositions were determined for duplicate $40 \mu \mathrm{g}$ samples hydrolyzed for 24,48 , and 72 hours, respectively. Values for serine and threonine were extrapolated to 0 hour, while those for valine and isoleucine were the average of 48 and 72 hours. Cysteine was determined as cysteic acid after Hirs (15) and tryptophan from the tyrosine/tryptophan ratio by the method of Benze and Schmid (2). All hydrolysates were analyzed on a Durrum D-500 amino acid analyzer.

Carbohydrate was determined by the method of DuBors et al. (9) using a glucose standard.

\subsection{Antibody production}

Antibodies were prepared against partly purified sorghum green malt immunogens as well as against purified $\beta$-amylase and two forms of $\alpha$ amylase. Total immunogens were extracted from $20 \mathrm{~g}$ lyophilized sorghum malt ( 5 day germination) in $100 \mathrm{ml} 0.2 \mathrm{M}-\mathrm{Na}$-acetate, $\mathrm{pH} 5.5,80$ mм- $\beta$-mercaptoethanol, $1 \mathrm{~mm}-\mathrm{CaCl}_{2}$, for 1 hour at $4{ }^{\circ} \mathrm{C}$. The extract was centrifuged twice at $25,000 \mathrm{x} \mathrm{g}$ for $15 \mathrm{~min}$ and filtered twice through two layers of miracloth and glass wool. The cleared, brownish supernatant was applied to a $2.5 \mathrm{x}$ $20 \mathrm{~cm}$ bed of LH-20 Sephadex equilibrated in $0.2 \mathrm{M}-\mathrm{Na}$-acetate, $\mathrm{pH} 5.5,1 \mathrm{mM}-\mathrm{CaCl}_{2}$, and eluted at approximately $200 \mathrm{ml} \cdot \mathrm{h}^{-1}$ in the equilibration buffer. Colored substances were strongly absorbed at the top of the gel. Eluted proteins were monitored at $280 \mathrm{~nm}$, the peaks pooled, extensively dialyzed against distilled water and lyophilized. Preparation of amylases for antigen production is described in section 2.8 .

Rabbits were immunized and tapped by Dakopatts, Copenhagen, Denmark using the im- munization schedule of INGILD \& HARBOE (1). The final immunization concentration of antigen was $2 \mathrm{mg} \cdot \mathrm{ml}^{-1}$ for the total-soluble green malt antigens and $150 \mu \mathrm{g} \cdot \mathrm{ml}^{-1}$ for the purified enzymes. Rabbits were injected with $1 \mathrm{ml}$ of the antigen/adjuvans mixture in three dorsal subcutaneous depots of $0.33 \mathrm{ml}$.

The IgG fraction was isolated from rabbit sera by $\left(\mathrm{NH}_{4}\right)_{2} \mathrm{SO}_{4}$ precipitation as described by $\mathrm{Ax}$ ELSEN et al. (1). Purified antibody was tested by immunodifusion and crossed immunoelectrophoresis against the appropriate antigens and stored at $4{ }^{\circ} \mathrm{C}$ in $15 \mathrm{~mm}-\mathrm{NaN}_{3}$.

\subsection{Molecular weight determination}

Molecular weights of purified proteins were estimated by SDS-PAGE and by gel filtration on Sephadex G75-superfine and Biogel P100. Gel filtration on a $2.5 \times 90 \mathrm{~cm}$ column of Sephadex was performed at $\mathrm{pH} 6.5$ in Na-acetate buffers of various ionic strengths. Chromatography on a 1.6 $\mathrm{x} 90 \mathrm{~cm}$ column of Biogel was performed in $0.2 \mathrm{M}-$ Tris- $\mathrm{HCl}, \mathrm{pH} 7.2,0.2 \mathrm{M}-\mathrm{NaCl}, 1 \mathrm{~mm}-\mathrm{CaCl}_{2}$ at a flow rate of $3-4 \mathrm{ml} \cdot \mathrm{h}^{-1}$. The columns were calibrated using the following molecular size standards: ferritin $\left(0.5 \mathrm{mg} \cdot \mathrm{ml}^{-1}\right)$ bovine serum albumin $\left(7 \mathrm{mg} \cdot \mathrm{ml}^{-1}\right)$, ovalbumin $\left(7 \mathrm{mg} \cdot \mathrm{ml}^{-1}\right)$, soya trypsin inhibitor $\left(5 \mathrm{mg} \cdot \mathrm{ml}^{-1}\right)$ and bovine ribonuclease $\left(10 \mathrm{mg} \cdot \mathrm{ml}^{-1}\right)$.

\subsection{Isolation of amylases}

Amylases were extracted from $100 \mathrm{~g}$ finely ground lyophilized sorghum green malt with $400 \mathrm{ml}$ of $0.2 \mathrm{M}-\mathrm{Na}$-acetate buffer, $\mathrm{pH} 5.5$, $80 \mathrm{~mm}-\beta$-mercaptoethanol and $1 \%$ insoluble PVP by stirring for 1 hour at $4{ }^{\circ} \mathrm{C}$. Following ethanol and glycogen precipitation according to Schramm and Loyter (28), the precipitate was resuspended in $50 \mathrm{~mm}$ - Na-acetate and incubated at $37^{\circ} \mathrm{C}$ for 1 hour to digest the glycogen. Insoluble material was removed by centrifugation at $40,000 \times \mathrm{g}$ for $15 \mathrm{~min}$.

Isolation and purification of amylases was carried out according to the flow chart in Fig. 1. All solutions used in chromatography contained $1 \mathrm{~mm}-\mathrm{CaCl}_{2}$ and all columns were run at $4{ }^{\circ} \mathrm{C}$. Column elution profiles were monitored for protein at $280 \mathrm{~nm}$, for $\alpha$-amylase activity with Phadebas blue starch tablets and by fused-rocket immunoelectrophoresis against anti-total sorghum 


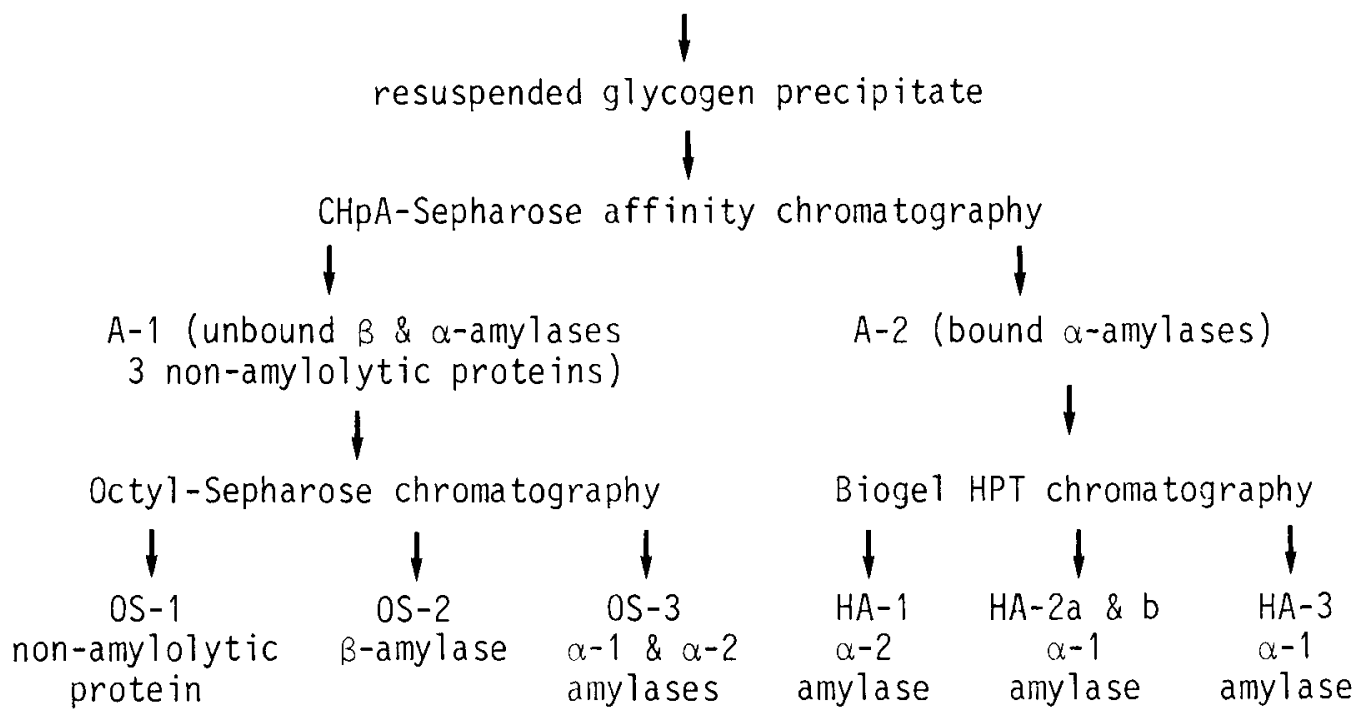

Figure 1. Sorghum $\alpha$-and $\beta$-amylase isolation flow scheme.

malt antigens. Purity of column fractions was checked by crossed immunoelectrophoresis and SDS-PAGE.

\subsubsection{Ion-exchange chromatography}

The resuspended glycogen precipitate was chromatographed on a $2.5 \times 25 \mathrm{~cm}$ column of DEAE-Sephadex A50 equilibrated with Tris$\mathrm{HCl}, \mathrm{pH} 7.2$. Elution was performed with a linear gradient of $\mathrm{NaCl}(0-0.5 \mathrm{M})$ at a flow rate of $15 \mathrm{ml} \cdot \mathrm{h}^{-1}$.

\subsubsection{Affinity chromatography}

CHpA-Sepharose 6B affinity chromatography was performed as described by SiLVANOVITCH and HizL (29) using 50mm-Na-acetate elution buffer, $\mathrm{pH} 5.5,1 \mathrm{~mm}-\mathrm{CaCl}_{2}$, at a flow rate of $35 \mathrm{ml} \cdot \mathrm{h}^{-1}$. Full release of the enzymes from the affinity gel was obtained with $8 \mathrm{mg} \cdot \mathrm{ml}^{-1}$ $\mathrm{CHpA}$ in the elution buffer.

\subsubsection{Hydroxylapatite chromatography}

The bound protein top from the $\mathrm{CHpA}$ affinity column (A-2) was concentrated in an Amicon concentrator fitted with a PM 10 membrane and the buffer changed to $10 \mathrm{~mm}$-phosphate buffer, $\mathrm{pH} 6.8$. The solution was applied to a $2.5 \times 30 \mathrm{~cm}$ column of Biogel HTP equilibrated in the phosphate buffer. Elution was performed with a linear gradient of phosphate buffer $(10-150 \mathrm{~mm})$ at a flow rate of $35 \mathrm{ml} \cdot \mathrm{h}^{-1}$.

\subsubsection{Hydrophobic interaction chromatography}

Unbound protein from the affinity column (A1) was concentrated and the buffer exchanged to $10 \mathrm{~mm}$-phosphate buffer, $\mathrm{pH}$ 6.8. The solution was $25 \%$ saturated with $\left(\mathrm{NH}_{4}\right)_{2} \mathrm{SO}_{4}$ at $4{ }^{\circ} \mathrm{C}$, allowed to stand at least 1 hour at $4{ }^{\circ} \mathrm{C}$ and then centrifuged at $20,000 \mathrm{xg}$ for $15 \mathrm{~min}$. The supernatant was chromatographed on a $1.5 \times 20 \mathrm{~cm}$ column of Octyl-Sepharose CL-4B as described by Pharmacia (16) using a decreasing linear gradient of $\left(\mathrm{NH}_{4}\right)_{2} \mathrm{SO}_{4}(25-0 \%)$ and an increasing linear gradient of ethyleneglycol $(0-50 \%)$.

\section{RESULTS AND DISCUSSION}

\subsection{Demonstration of two immunologically distinct forms of $\alpha$-amylase}

Crossed immunoelectrophoresis of total sorghum malt extracts versus anti-total sorghum malt antigens revealed three amylolytic peaks among a total of 15-20 protein peaks (Figures 2a and $b$ ). These enzymes are $\beta$-amylase and two $\alpha$ amylases which have been named $\alpha-1$ (most anodic) and $\alpha-2$ amylase solely according to their mobility in the alkaline gel ( $\mathrm{pH} 8.6$ ). $\alpha-1$ (major malt $\alpha$-amylase) and $\beta$-amylase are readily visi- 


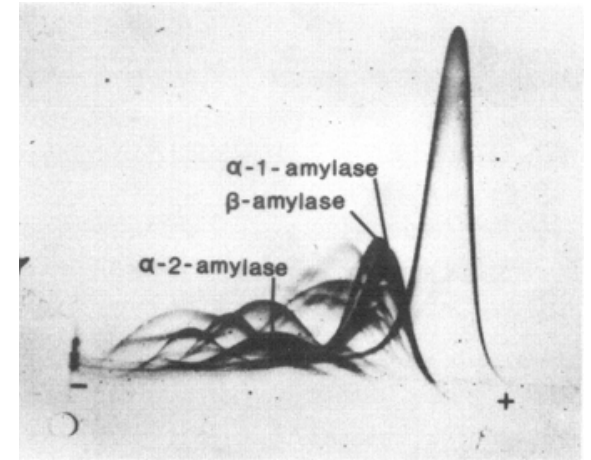

Figure 2a. Total sorghum malt ( 5 day) antigens ( $15 \mu \mathrm{l}$, $10 \mathrm{mg} \cdot \mathrm{ml}^{-1}$ vs. $200 \mu \mathrm{l}$ anti-total malt rabbit IgG fraction.

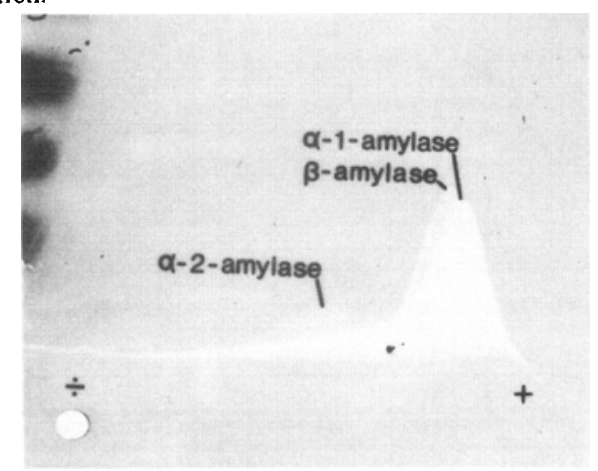

Figure 2b. Amylogram of the gel shown in Figure 2a incubated and developed after (14).

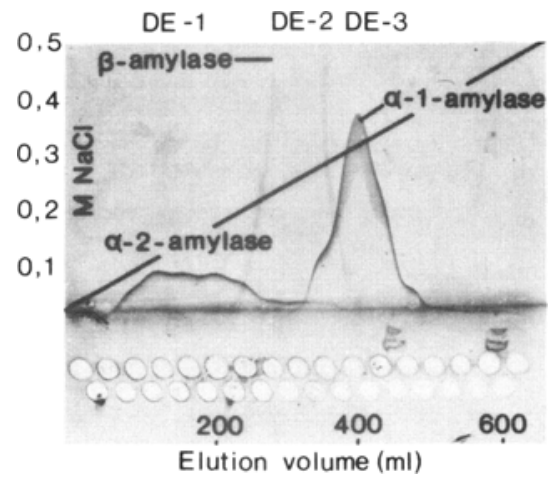

Figure 3. Fused rocket immunoelectrophoretogram of DEAE-Sephadex column fractions vs. $250 \mu \mathrm{l}$ anti-total malt rabbit IgG.

Note: $\beta$-amylase top is diffuse due to low titre in serum used.

ble in 1-dimensional gels but the activity of $\alpha-2$ amylase is generally too low to be seen.

The same amylolytic enzyme pattern is seen in the elution profile of a glycogen precipitate chromatographed on DEAE-Sephadex (Figure 3).

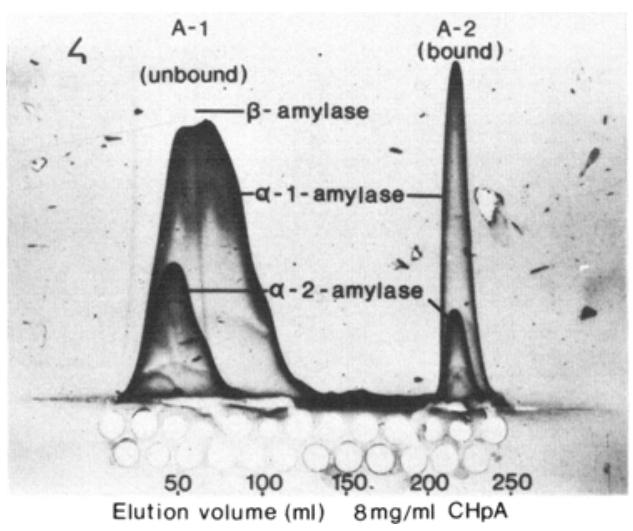

Figure 4. Fused rocket immunoelectrophoretogram of $\mathrm{CHpA}$-Sepharose affinity column fractions vs. $150 \mu \mathrm{l}$ anti-total malt rabbit IgG.

The amylases elute from the ion-exchanger in order of their isoelectric points (see below).

$\alpha-1$ and $\alpha-2$ are separated from $\beta$-amylase by affinity chromatography on $\mathrm{CHpA}$-Sepharose (Figure 4). It was not possible to differentially elute one of the bound $\alpha$-amylases using gradients of $\mathrm{NaCl}$ or $\beta$-limit dextrin. Ouchterlony immunodiffusion and crossed immunoelectrophoresis showed that the $\alpha$-amylases present in the unbound affinity top (A-1) are immunologically identical to the enzymes binding to the column. Subsequent runs with less enzyme showed saturation of the gel at an $\alpha$-amylase concentration of approximately $1.1 \mathrm{mg}$ protein $\cdot \mathrm{ml}^{-1}$ gel.

The two $\alpha$-enzymes are separated by DEAESephadex chromatography but chromatography

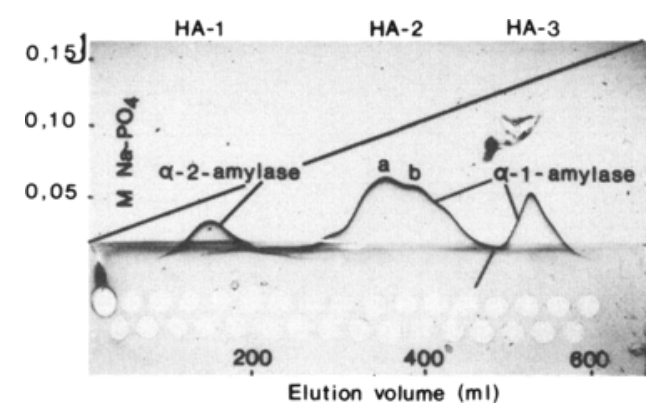

Figure 5. Fused rocket immunoelectrophoretogram of hydroxylapatite column fractions vs. $300 \mu$ anti-total malt rabbit IgG. 


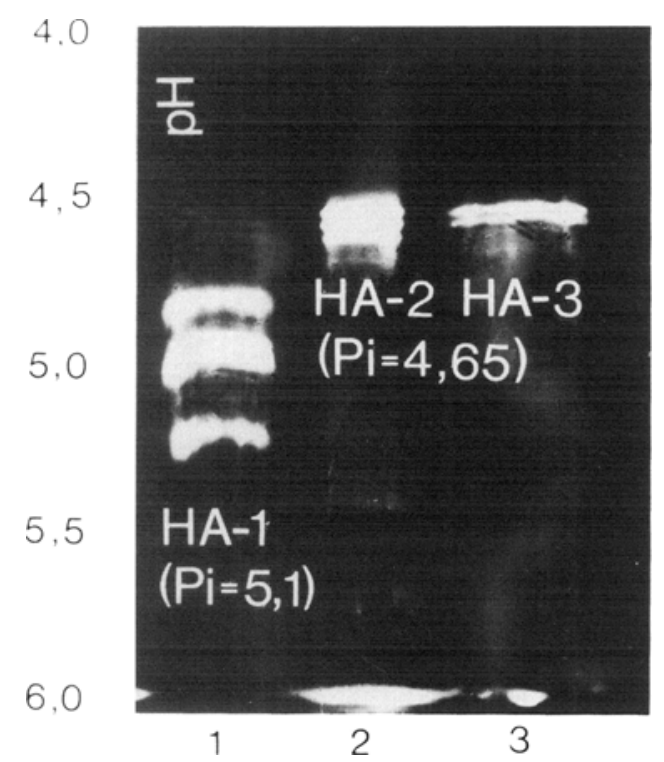

Figure 6. IEF-PAGE (pH 4-6) of hydroxylapatite column fractions.

Lane 1, HA-1 ( $40 \mu \mathrm{g}, \alpha-2)$. Lanes 2 and 3, HA-2 \& 3 $(10 \mu \mathrm{g}, \alpha-1)$.

on hydroxylapatite separated $\alpha-2$ from $\alpha-1$ and resolved the $\alpha-1$ component into two separate tops referred to as HA-2 and HA-3 (Figure 5). It should be noted that peaks HA-2 and HA-3 are immunologically identical and that the HA-2 peak furthermore appears to be a double peak. This pattern of separation was reproducible and was not due to overloading; chromatography of an identical preparation on a larger column produced the same separation. Although the mechanism of the interaction between hydroxylapatite and enzymes is unknown, $\mathrm{Ca}_{3}\left(\mathrm{PO}_{4}\right)_{2}$ may be particularly well suited for the separation of $\mathrm{Ca}^{+2}$ dependent enzymes such as $\alpha$-amylase.

Isoelectric focusing (Figure 6) of the three peaks from the hydroxylapatite column revealed up to 3 bands ( 1 major, 2 minor) at pI 5.1 for $\alpha-2$ amylase (HA-1) and always 3 closely spaced bands at pI 4.65 for $\alpha-1$ amylase (HA-2\&3). The outermost two bands of the $\alpha-2$ group are electrophoretic artefacts; refocusing the major $\alpha-2$ band ( $\mathrm{pI} 5.1$ ) results in the accumulation of broad bands of activity extending to the two outer bands. Refocusing the 3 bands of the $\alpha-1$ group does not indicate artefact formation and their banding pattern is reproducible in IEF-PAGE gels containing $0.5 \% \beta$-limit dextrin. That these three bands may represent in vivo multiple molecular forms of $\alpha$-amylase $\left(\alpha-1_{a}, 1_{b}, 1_{c}\right)$ is supported by differences in the isoelectric focusing pattern of $\alpha-1$ amylase separated into fractions HA-2 and HA-3 (Figure 6).

It is concluded from these results that sorghum malt contains two immunologically distinct forms of $\alpha$-amylase named $\alpha-1\left(1_{a}, 1_{b}, 1_{c}\right)$ and $\alpha-2$ amylase which are separable chromatographically and which have different isoelectric points. The chromatographic results are in agreement with Botes et al. (4) who postulated the presence of $4 \alpha$-amylase isozymes in sorghum malt from an activity/absorption profile of purified $\alpha$-amylase chromatographed on hydroxylapatite. In Table I it can be seen that $\alpha-2$ accounts for up to $25 \%$ by weight but only for some $2 \%$ of the saccharifying $\alpha$-amylase activity in the sorghum variety used in this study. Speculation on the in vivo significance of the three forms of $\alpha-1$ amylase must await further study. The reader is referred to (11) for a discussion of isozyme classification.

Adequate separation of $\beta$-amylase from the $\alpha$ amylases for mono-specific antibody production could not be achieved using ion-exchange columns. The differential precipitation of sorghum $\alpha$-amylase from $\beta$-amylase reported by BoTEs et al. (4) combined with the suspected hydrophobicity of the $\alpha$-amylases seen in gel filtration experiments (section 3.2.1.) suggested the use of hydrophobic interaction chromatography for

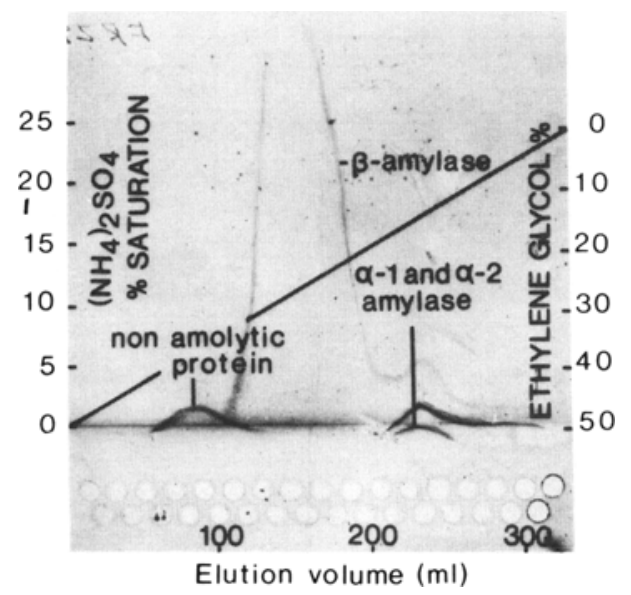

Figure 7. Fused rocket immunoelectrophoretogram of Octyl-Sepharose column fractions vs. $125 \mu l$ anti-total malt rabbit IgG. 
Table I.

Purification and yields of sorghum $\alpha$-amylases isolated by affinity and hydroxylapatite chromatography

\begin{tabular}{lccccc}
\hline & $\begin{array}{c}\text { Phabedas total } \\
\text { units }\end{array}$ & Total mg protein & $\begin{array}{c}\text { Spec. Act. units/mg } \\
\text { protein }\end{array}$ & \% yield units & $\begin{array}{c}\text { \% yield } \\
\text { protein }\end{array}$ \\
\hline Crude extract & $5.4 \times 10^{8}$ & $18 \times 10^{3}$ & $3.0 \times 10^{4}$ & 100.0 & 100.0 \\
Glycogen ppt. & $6.4 \times 10^{7}$ & 81.25 & $7.8 \times 10^{5}$ & 11.8 & 0.45 \\
A-1 (unbound) & $4.0 \times 10^{7}$ & 53.0 & $7.5 \times 10^{5}$ & 7.4 & 0.29 \\
A-2 (bound) & $2.3 \times 10^{7}$ & 26.5 & $8.8 \times 10^{5}$ & 4.2 & 0.15 \\
HA-1 $(\alpha-2)$ & $3.6 \times 10^{5}$ & 2.6 & $1.4 \times 10^{5}$ & - & 0.01 \\
HA-2 $(\alpha-1)$ & $3.0 \times 10^{7}$ & 10.3 & $2.9 \times 10^{6}$ & 5.5 & 0.06 \\
\hline
\end{tabular}

separating $\beta$ - from $\alpha$-amylase. $25 \%\left(\mathrm{NH}_{4}\right)_{2} \mathrm{SO}_{4}$ saturation of fraction $\mathrm{HA}-1$ resulted in precipitation of $20-30 \%$ of the $\alpha$-amylase activity and 2 of the non-amylolytic proteins present in the glycogen precipitate. The $25 \%\left(\mathrm{NH}_{4}\right)_{2} \mathrm{SO}_{4}$ supernatant gave three protein peaks when chromatographed on Octyl-Sepharose (Figure 7). OS-1 is a non-amolytic protein, OS-2 is $\beta$ amylase and OS-3 contains both $\alpha-1$ and $\alpha-2$ amylase. The retarded elution of the $\alpha$-amylases indicates that they are relatively hydrophobic, a property which may partly explain the low amylolytic power of sorghum malt extracts compared with extracts of barley malt.

\subsection{Physical and chemical characterization of amylases}

Physical and chemical properties of $\alpha-1$ and $\alpha$ 2 amylase are summarized in Table II.

\subsubsection{Molecular weight determination}

The molecular weights of $\beta$ - and $\alpha$-amylases were calculated from SDS-PAGE and by gel filtration. SDS-PAGE yielded values of 53,000 for $\beta$-amylase, 41,500 for $\alpha-1$ and $41,500-42,700$ for $\alpha-2$ (Figure 8 ). $\alpha-2$ amylase runs as a disperse band on all gels examined, a peculiarity which may be due to its higher carbohydrate content

Figure 8. SDS-PAGE of total malt extracts and pooled column fractions. Lanes $1-4,0,1,3,5$ day malt extracts.

Lane 5, glycogen precipitate. Lane 6, CHpASepharose fraction A-2 (bound). Lane 7, hydroxylapatite fraction HA-2 (10 $\mu \mathrm{g} \alpha$-1-amylase) and lane 8, fraction HA-1 (40 $\mu \mathrm{g} \alpha$-2-amylase) . Lane 9, DEAESephadex fraction DE-2 (15 $\mu$ g partially purified $\beta$ amylase). Lane 10, molecular size standards (Daltons).
Table II.

Comparison of properties of sorghum $\alpha$-amylases

\begin{tabular}{|c|c|c|}
\hline & orghum $\alpha-1$ & sorghum $\alpha-2$ \\
\hline $\mathrm{pH}$ optima & $5.0-6.5$ & $4.5-6.5$ \\
\hline $\begin{array}{l}\mathrm{K}_{\mathrm{m}}\left(10^{-4} \mathrm{~g} \cdot \mathrm{starch} \cdot \mathrm{ml}^{-1}\right) \\
\mathrm{Vmax}(\mu \text { mole mal- } \\
\text { tose } \cdot \mathrm{min}^{-1} .\end{array}$ & 3.6 & 0.7 \\
\hline $\mathrm{mg}^{-1}$ enzyme at $25^{\circ} \mathrm{C}$ ) & 1460 & 0.01 \\
\hline $\mathrm{Q}_{10}\left(20-30^{\circ} \mathrm{C}\right)$ & 2.2 & 1.3 \\
\hline $\mathrm{Q}_{10}\left(30-40^{\circ} \mathrm{C}\right)$ & 1.6 & 1.2 \\
\hline $\begin{array}{l}\mathrm{K}_{\mathrm{m}}\left(10^{-4} \mathrm{~g} \text { blue }\right. \\
\text { starch } \cdot \mathrm{ml}^{-1}\end{array}$ & 68.6 & 4.25 \\
\hline $\begin{array}{l}\mathrm{K}_{\mathrm{i}}\left(10^{-4} \mathrm{~g} \mathrm{CHpA} \cdot \mathrm{ml}^{-1}\right) \\
1^{\circ} \text { soluble starch }\end{array}$ & $\left.5^{1}\right)$ & $\left.4.3-6.7^{2}\right)$ \\
\hline $\begin{array}{l}\text { hydrolysis products } \\
\text { molecular weight }\end{array}$ & \multicolumn{2}{|c|}{$\left.G_{2}, G_{3}, G_{1}^{3}\right) D P\left(6-8^{4}\right), G_{2}$} \\
\hline (Daltons) & 41,500 & $41,500-42,700$ \\
\hline$\%(w / w)$ carbohydrate & 0.7 & 5.7 \\
\hline $\mathbf{P}_{\mathrm{i}}$ & 4.65 & 5.1 \\
\hline
\end{tabular}

1) competitive ${ }^{2}$ ) non-competitive $\left.{ }^{3}\right) \mathrm{G}=$ glucose residue $\left.^{4}\right) \mathrm{DP}=$ degree of polymerization

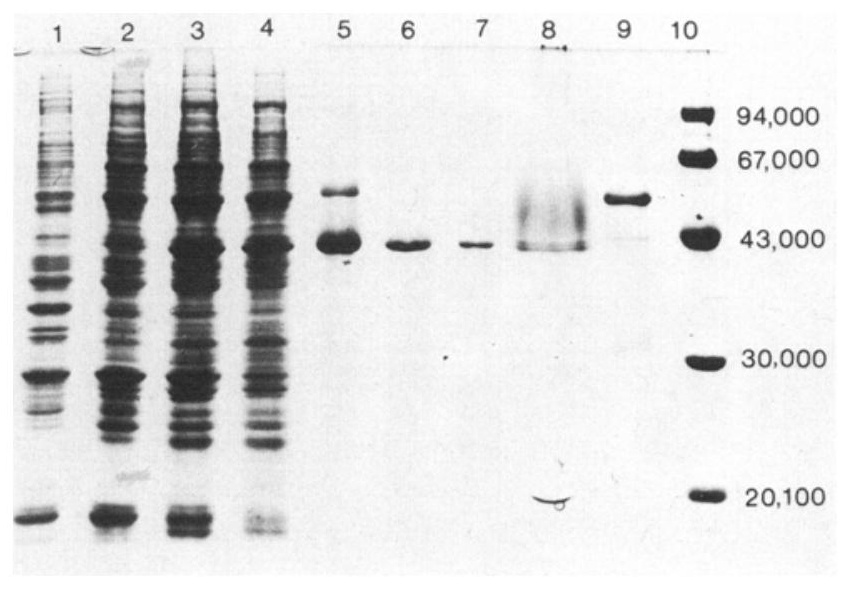


(section 3.2.2). Although the band at 20,000 in lane 8 was not reproducible, it should be noted that RoDAWAY (26) described the co-purification with barley $\alpha-2$ amylase of a dimer of 43,000 (monomer weight $=21,500)$ called band-2 protein. Given the low activity of $\alpha-2$ amylase, the possibility cannot be excluded that $\alpha-2$ preparations contain a co-purified $\alpha$-amylase inhibitor with a subunit weight of approximately 20,000.

The electrophoretic results are in agreement with molecular weights obtained by molecular exclusion chromatography. Gel filtration on Sephadex G75 superfine in $50 \mathrm{~mm}-\mathrm{Na}$-acetate, $\mathrm{pH}$ 6.5, and on Biogel P-100 in 0.2M-TRIS-HCl, $\mathrm{pH} 7.2$ gave a molecular weight of approximately 52,500 for $\beta$-amylase. In contrast, $\alpha-1$ and $\alpha-2$ were retarded on these columns, both eluting as two broad peaks at 30,000 and 8,000 from the Sephadex gel. At higher ionic strength $(0.2 \mathrm{M}$ $\mathrm{Na}$-acetate, $0.3 \mathrm{M}-\mathrm{NaCl}$ ) the two $\alpha$-amylases elute from the Sephadex gel at 36,000-38,000. Biogel $\mathrm{P}-100$ chromatography in $0.2 \mathrm{M}$-TRIS and 0.4 $\mathrm{M}-\mathrm{NaCl}$ showed a major top at $39,000-42,000$ and a minor top at 50,000 (Figure 9). Although Botes et al. (4) obtained a weight of approx-

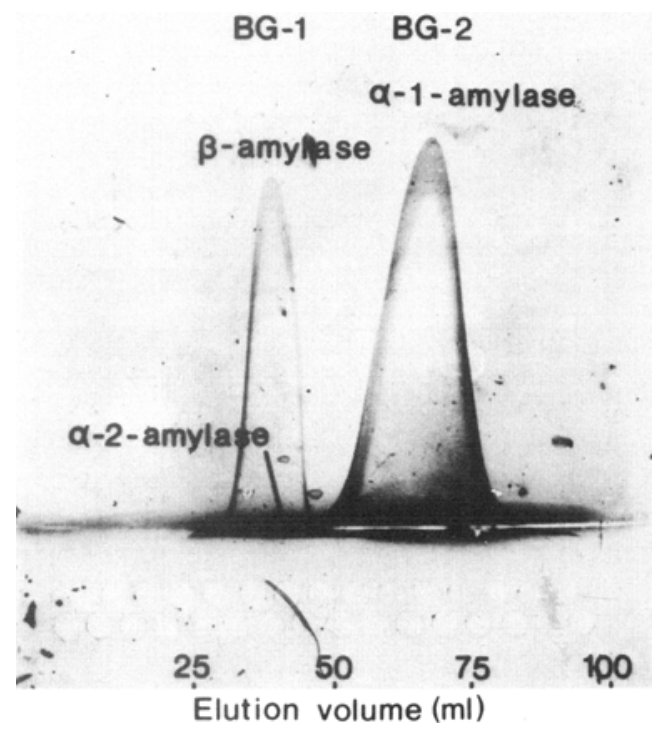

Figure 9. Fused rocket immunoelectrophoretogram of Biogel P-100 column fractions vs. $250 \mu \mathrm{l}$ anti-total malt IgG.

Material used in this run is combined DEAESephadex fractions DE-2 \& 3 . Low $x-2$ content is due to incomplete separation of $x-2$ from $\beta$-amylase in ionexchange chromatography. imately 48,000 for sorghum $\alpha$-amylase in ultracentrifuge studies, values between 40,000 and 45,000 are most commonly reported in recent investigations of cereal $\alpha$-amylases $(26,30,31$,). The higher value of 48,000 may be due either to contamination of the $\alpha$-amylase preparation with $\beta$-amylase or to a slight underestimation of the partial specific volume of $\alpha$-amylase employed in the ultracentrifuge determination. To insure that the lower molecular weight obtained in the present study was not due to degradation of $\alpha$ amylase by proteases during extraction, total malt extracts were made with buffers containing EDTA, and the serine proteinase inhibitors phenyl-methyl-sulfonyl chloride and $n-\alpha-p$ tosyl-Llysine. SDS-PAGE of these extracts and of their glycogen precipitates produced patterns identical to those of normal $\mathrm{Na}$-acetate extracts.

\subsubsection{Amino acid analysis and carbohydrate content}

Results of the amino acid analysis for $\alpha-1$ and $\alpha-2$ are given in Table III along with values extrapolated from Botes et al. (4) for sorghum malt $\alpha$-amylase and for wheat and barley $\alpha$ amylase $(26,31)$. It is seen that $\alpha-1$ and $\alpha-2$ from sorghum have similar compositions except for differences in Ser, Val, Ile, and Cys. The comparative composition data for sorghum, barley and wheat, considered together with the partial immunological identity between the sorghum $\alpha-1$ and barley $\alpha-2$ amylases (section 3.3), indicates that there is extensive amino acid homology between the germination $\alpha$-amylases of sorghum, barley and wheat. The major difference between the sorghum and barley $\alpha$-amylases is a higher number of Ile and Leu and a lower number of His, Lys, and Arg residues in the former. This explains the lower isoelectric point found for sorghum $\alpha$-amylase(pI 4.65 for $\alpha$-1) versus that for barley $\alpha-2$ amylase and malted wheat $\alpha$ amylase (pl 6.1, see 19,31).

Using the phenol- $\mathrm{H}_{2} \mathrm{SO}_{4}$ reagent of DuBors et al. (9), $\alpha-1$ and $\alpha-2$ showed $0.7 \%$ and $5.7 \%(w / w)$ carbohydrate respectively.

\subsubsection{Kinetics and action patterns of $\alpha$-amylases}

The kinetic properties of the $\alpha$-amylases are summarized in Table II. The values for $\alpha-1$ are similar to those reported from other cereals (30). 
The much lower $\mathrm{Km}$ and $\mathrm{Vmax}$ values for $\alpha-2$ compared with $\alpha-1$ are in keeping with the much lower specific activity of $\alpha-2$ preparations and with the differences in the action patterns of the two enzymes on soluble starch.

Lineweaver-Burke plots showed that $\alpha-1$ is competitively inhibited by $\mathrm{CHpA}$ at concentrations of 1 and $4 \mathrm{mg} \cdot \mathrm{ml}^{-1}$ with a $\mathrm{Ki}$ of $0.05 \cdot 10^{-4} \mathrm{~g} \cdot \mathrm{ml}^{-1}$. Higher concentrations of CHpA result in a loss of activity without a loss in specific activity which is presumably due to precipitation of the enzyme. $\alpha-2$ is also inhibited by $\mathrm{CHpA}$ but the pattern of inhibition approximates that of a noncompetitive inhibitor with a $\mathrm{Ki}$ of $0.043-0.070 \times 10^{-4} \mathrm{~g} \cdot \mathrm{ml}^{-1}$.

These results for $\alpha-1$ are in agreement with a

\section{Table III}

Amino acid compositions of sorghum, barley, $\&$ wheat $\alpha$-amylases (number of amino acid residues per protein molecule)

\begin{tabular}{|c|c|c|c|c|}
\hline & \multicolumn{2}{|c|}{ sorghum sorghum } & \multicolumn{2}{|c|}{ sorghum ${ }^{1}$ ) barley wheat ${ }^{2}$ ) } \\
\hline & $\alpha^{-1}$ & $\alpha^{-2}$ & (4) & (26) $(26,31)$ \\
\hline sp & 50.0 & 47.3 & 54.2 & 49.141 \\
\hline Thr & 15.2 & 13.8 & 16.5 & $16.0 \quad 20$ \\
\hline er & 13.9 & & & 13.920 .4 \\
\hline lu & 3 & 4 & & 26.54 \\
\hline Pro & 18.2 & 17.5 & 18.4 & $19.6 \quad 26.1$ \\
\hline Met & 5.2 & 5.3 & 4 & 6.2 \\
\hline ly & 46.1 & 45.0 & 48.7 & $46.2 \quad 42.0$ \\
\hline a & 32.3 & 35.0 & 36.9 & $33.2 \quad 33.0$ \\
\hline al & 21.6 & 26.9 & & $22.3 \quad 24.8$ \\
\hline e & 21.9 & 15.4 & 1.6 & $\begin{array}{ll}7.2 & 19.9\end{array}$ \\
\hline Leu & 28.7 & 26.5 & 27.7 & $25.3 \quad 27$ \\
\hline Tyr & 15.1 & 6.1 & 14.6 & $14.3 \quad 12$ \\
\hline Phe & 16.5 & 1 & 16.7 & $16.8 \quad 14$ \\
\hline lis & 2 & 1. & 4 & $16.2 \quad 12.8$ \\
\hline Lys & 17.3 & 17.9 & 16.1 & $22.2 \quad 18.8$ \\
\hline Arg & 13.6 & 12.4 & 14.7 & $\begin{array}{ll}16.7 & 17.3\end{array}$ \\
\hline $1 / 2$ Cys & $\left.3.7^{3}\right)$ & $\left.5.6^{3}\right)$ & $\left.3.4^{4}\right)$ & -5) $\left.4.4^{3}\right)$ \\
\hline Trp & $\left.9.6^{6}\right)$ & $\left.11.3^{6}\right)$ & - & 11.0 \\
\hline Total & 376.2 & 375.6 & 77.6 & 362.0391 .8 \\
\hline \multicolumn{5}{|c|}{$\begin{array}{l}\text { 1) determined from } \% \mathrm{w} / \mathrm{w} \text { values adjusted for } \alpha \text { - } \\
\text { amylase of } 41,500 \text { molecular weight, Trp content }= \\
4.1 \% \text { from this study }{ }^{2} \text { ) molecular weight given as } \\
\left.43,300^{3} \text { ) as cysteic acid after }(14)^{4}\right) \text { as } 1 / 2 \text { Cys CySH } \\
\text { ) } \\
\text { not determined } 6 \text { ) from spectrophotometric determina- } \\
\text { tion of } \operatorname{Trp} / \operatorname{Tyr} \text { ratio after (2) }\end{array}$} \\
\hline
\end{tabular}

recent study of CHpA inhibition of Triticale $\alpha$ amylase (32) which reported from equilibrium dialysis experiments that the CHpA-enzyme interaction must occur at a site other than the active site. The same study suggested that $\alpha$ amylase can accomodate a number of $\mathrm{CHpA}$ molecules and that this may cause aggregation and precipitation as is seen with glycogen complexes (18). It is well documented (3) that cyclodextrins form inclusion complexes with hydrophobic molecules in aqueous solution. The partially hydrophobic character of sorghum $\alpha$ amylase seen in the present study suggests that part of the inhibitory action of $\mathrm{CHpA}$ may be due to hydrophobic interactions with the enzyme.

The action pattern of the $\alpha$-amylases on soluble starch is shown in Figure 10. The primary hydrolysis products of $\alpha-1$ amylase are maltose, maltotriose and glucose while that of $\alpha-2$ are oligosaccharides of DP 6-8 and some maltose and maltotriose. In the incubations shown, the amount of enzyme is very high and $10 \mathrm{x}$ as much $\alpha-2$ by weight is used than $\alpha-1$. In similar experiments with equal numbers of Phadebas units, the same differences are seen, i.e. $\alpha-2$ produces quan-

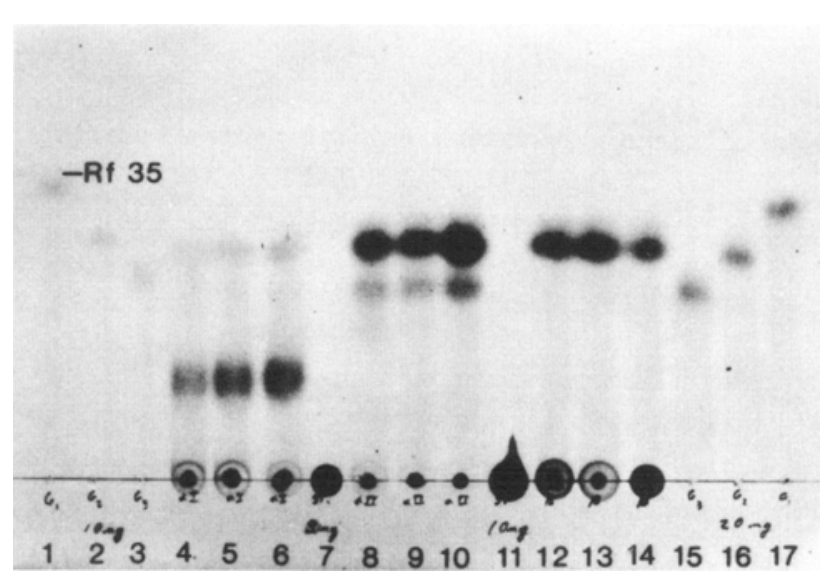

Figure 10. Thin layer chromatogram showing the products of the hydrolysis of soluble starch by sorghum $\alpha$ amylases and $\beta$-amylase.

Lanes 1-3, $10 \mu \mathrm{g} \mathrm{G}_{1}, \mathrm{G}_{2}, \mathrm{G}_{3}$. Lanes 4-6, 2,10,45 min. incubation of $20 \mu \mathrm{g} 1 \%$ soluble starch with $25 \mu \mathrm{g} \alpha-2$ amylase (fraction HA-1) . Lane 7, $10 \mu \mathrm{g}$ starch. Lanes 8-10, 2,10,45 min. incubation of $20 \mu \mathrm{g}$ starch with 2.5 $\mu \mathrm{g} \alpha-1$-amylase (fraction HA-2). Lane 11, $20 \mu \mathrm{g}$ starch. Lanes 12-14, 2,10,45 min. incubation of $20 \mu \mathrm{g}$ starch with $25 \mu \mathrm{g} \beta$-amylase(fraction OS-2). Lanes 15-17, 20 $\mu \mathrm{g} \mathrm{G}_{3}, \mathrm{G}_{2}, \mathrm{G}_{3}$. 
titatively more of the DP 6-8 oligosaccharides than $\alpha-1$. Similar incubations with pullulan as substrate showed that neither of the sorghum $\alpha$ amylases could hydrolyze $\alpha(1->6)$ glucosidic linkages. The production of high concentrations of DP 6-8 oligosaccharides previously reported as a peculiarity of sorghum $\alpha$-amylase (4) is therefore attributable to the $\alpha-2$ form of the enzyme. During prolonged incubations (up to 48 hours) with high concentrations of $\alpha-2$ or with equal mixtures of $\alpha-1$ and $\alpha-2$, the concentration of the DP 6.8 oligosaccharides decreases until only $G_{1}$, $G_{2}$, and $G_{3}$ remain. It is not known whether the DP 6-8 oligosaccharides are inhibitory to the action of sorghum $\alpha$-amylase.

These physico-chemical data suggest that $\alpha-1$ and $\alpha-2$ are either post-translationally modified forms of the same polypeptide or that they are isozymes coded for by different genes. The possibility that $\alpha-2$ preparations contain a co-purified protein of approximately 42,000 daltons (subunit weight approximately 20,000 ) is being investigated by chromatography and electrophoresis under strongly denaturing conditions.

\subsection{Immunological comparision of sorghum and barley germination amylases}

Crossed immunoelectrophoresis of sorghum malt extracts showed that $\alpha-1$ is present in trace amounts in ungerminated sorghum and that both $\alpha-1$ and $\alpha-2$ amylase increase during malting. Ouchterlony immunodiffusion of the enzymes against monospecific anti- $\alpha-1$ and anti- $\alpha-2$ amylase showed that there is partial identity between $\alpha-1$ and $\alpha-2$ and confirmed that $\alpha-2$ precipitins are amylolytic.

Immunodiffusion and crossed immuno- electrophoresis of sorghum $\alpha-1$ amylase against anti-total barley malt immunogens and monospecific anti-barley $a-2$ amylase showed immunological identity between these two major malt enzymes (Figure 11). No similar reaction was seen for sorghum $\alpha-2$ amylase. It is concluded that barley $\alpha-2$ amylase displays extensive structural homology with sorghum $\alpha$-1 amylase, while the sorghum $\alpha-2$ form of the enzyme does not appear to have an immunological counterpart in barley malt.

\section{CONCLUDING REMARKS}

This communication presents evidence to show that barley $\alpha-2$ and sorghum $\alpha-1$ malt amylases have similar molecular weights, amino acid compositions, kinetic properties and immunological determinants. In addition to the major $\alpha-1$ amylase, sorghum malt contains an immunologically distinct form of $\alpha$-amylase called $\alpha-2$ amylase. Preliminary kinetic analysis indicates that the very low saccharifying activity of $a-2$ amylase is due to a different substrate specificity than that of the major $\alpha-1$ form of the enzyme.

\section{ACKNOWLEDGEMENTS}

I wish to express my gratitude to Fil. Dr. LARS MuncK and Dr. Gregory GibBons who greatly influenced this work through guidance and discussion. I especially thank Dr. Iв JoNASSEN and Professor BENT FoltMann for their suggestions during the isolation experiments. The work of Civ. Ing. LARS HALLGREN and the technical assistance of Bodil Stilling, and Bodil CoRNELIUSSEN with the amino acid analyses and of ANNETtE HANSEN for preparing the figures is gratefully acknowledged.

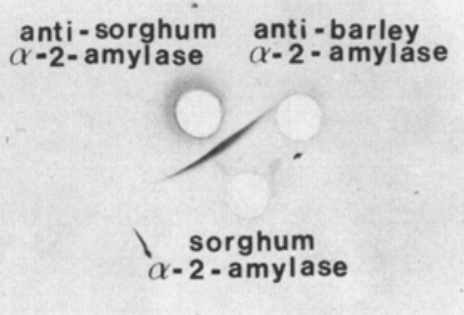

Figure 11. Ouchterlony double diffusion of sorghum $\alpha-1$ and $\alpha-2$ amylases against monospecific anti-barley $\alpha-2$, antisorghum $\alpha-1$, and anti-sorghum $\alpha$-2 amylases. $15 \mu \mathrm{l}$ of each antiserum vs. $6 \mu \mathrm{g}$ antigen. 


\section{REFERENCES}

1. Axelsen, N.H., J. Krøll \& B. Weeke (eds.): A Manual of Quantitative Immunoelectrophoresis. Methods and Applications. Universitetsforlaget. Oslo (1973)

2. Benze, W.L. \& K. SChMiD: Determination of tyrosine and tryptophan in proteins. Anal. Chem. 29, 1193-1196 (1957)

3. Bender, M.L. \& M. KomiYama: Cyclodextrin Chemistry. pp.10-27. Springer-Verlag (1978).

4. Botes, D.P., F.J. Joubert \& L. Novellie: Kaffirkorn malting and brewing studies XVII Purification and properties of sorghum malt $\alpha$ amylase. J. Sci. Fd. Agric. 18, 409-415 (1967)

5. ChaO, S.E. \& J.G. Scandalios: Alphaamylase of maize: differential allelic expression at the AMY-l gene locus, and some properties of the enzymes. Genetics 69, 47-61 (1971)

6. Chrispeels, M.J. \& J.E. VARner: Gibberellic acid-enhanced synthesis and release of $\alpha$ amylase and ribonuclease by isolated barley aleurone layers. Plant Phys. 42, 398-406 (1967)

7. DaIBER, K.H.: Enzyme inhibition by polyphenols of sorghum grain and malt. J. Sci. Fd. Agric. 11, 408-421 (1975)

8. Daussant, J. \& A. Skakoun: Immunochemical approaches to studies of isozyme regulation in higher plants. In: Isozymes, current topics in biological and medical research. 5, 175-218 (1981)

9. Dubois, M., K.A. Gilles, J.K. Hamilton, P.A. Rebers \& F. SMrth: Colorimetric method for determining sugars and related substances. Anal. Chem. 28, 350-356 (1956)

10. Dygert, S., L.H. LI, D. Florida \& J.A. Tнома: Determination of reducing sugar with improved precision. Anal. Biochem. 13, 367 . 374 (1965)

11. Enzyme Nomenclature. Recomendations (1972) of IUPAC and the International Union of Biochemistry. Chapter 3 (1973) Academic Press.

12. Frydenberg, O. \& G. Nielsen: Amylase isozymes in germinating barley seeds. Hereditas 54, 123-139 (1965)

13. GibBons, G.C: On the localization and transport of $\alpha$-amylase during germination and early seedling growth of Hordeum vulgare. Carlsberg Res. Comm. 44, 353-366 (1979)

14. HejgaArd, J: Free and protein-bound $\beta$ amylases of barley grain - Characterization and two-dimensional electrophoresis. Physiol. Plant. 38, 293-299 (1976)

15. HiRs, C.H.W.: Determination of cystine as cysteic acid. Meth. Enzymol. 11, 59-62 (1962)
16. Hydrophobic interaction chromatography: Octyl and Phenyl-Sepharose. Pharmacia application note.

17. Koller, A. \& H. Neukon: Detection of oligogalacturonic acids by thin-layer chromatography. Biochim. Biophys. Acta. 83, 366367 (1969)

18. Levitski, A., J. Heller \& M. Schramm: Specific precipitation of enzyme by its substrate: The $\alpha$-amylase-macrodextrin complex. Biochem. Biophys. Acta. 81, 101-107 (1964)

19. MacGregor, A.W., D.E. La Berge \& W.O.S. Meredith: Separation of $\alpha$ and $\beta$-amylase enzymes from barley malt by ion-exchange chromatography. Cereal Chem. 48, 490-498 (1971)

20. MacGregor, A.W. \& J. Daussant: Evolution of $\alpha$-amylase components during initial stages of barley germination with and without prior steeping. Cereal Chem. 56, 541-545 (1979)

21. MozeR, T.J.: Control of protein synthesis in barley aleurone layers by the plant hormones gibberellic and abscisic acid. Cell. 20, 479-485 (1980)

22. NevilLe, D.M. JR.: Molecular weight determinations of protein - dodecyl sulfate complexes in gel electrophoresis in a discontinuous buffer system. J. Biol. Chem. 246,6328-6334 (1971)

23. Novellie, L.: Kaffirkorn malting and brewing studies. IV. The extraction and nature of the insoluble amylases of kaffirkorn malts. J. Sci. Fd. Agric. 11, 408-421 (1960)

24. OKamoto, K. \& T. Akazawa: Enzyme mechanisms of starch breakdown in germinating rice seeds VII. Amylase formation in the epithelium. Plant. Physiol. 63, 336-340 (1979)

25. Olered, R. \& G. JonsSON: Electrophoretic studies of $\alpha$-amylase in wheat II. J. Fd. Sci. Agric. 21, 385-392 (1970)

26. RoDAWAY, S.J.: Composition of $\alpha$-amylase from aleurone layers of grains of Himalaya Bareley. Phytochem. 17, 385-389 (1978)

27. Scandalios, J.G. Isozymes in development and differentiation. Ann. Rev. Plant Phys. 25, 225258 (1974)

28. Schramm, M. \& A. Loyter: Purification of $\alpha$ amylases by precipitation of $\alpha$-amylaseglycogen complexes. Meth. Enzymol. 8, 533537 (1966)

29. Silvanovitch, M.P. \& R.D. Hill: Affinity chromatography of cereal $\alpha$-amylase. Anal. Biochem. 73, 430-433 (1976)

30. Silvanovitch, M.P. \& R.D. Hill: $\alpha$-amylases from Triticale 6A190: Purification and characterization. Cereal Chem. 54, 1270-1280 (1977) 
31. Tkachuk, R. \& J.E. Kruger: Wheat $\alpha$ amylase II. Physical characterization. Cereal Chem. 51, 508-529 (1974)

32. Weselake, R.J. \& R. D. Hill.: Cycloheptaamylose as an affinity ligand of cereal $\alpha$ amylase. Characteristics and a possible mechanism of the interaction. (submitted to Carbohydrate Research, June 1982)
33. WhELAN, W.J.: Hydrolysis with $\alpha$-amylase. In: Methods in Carbohydrate Chemistry vol. 4, R.C. Whistler (ed.) pp. 252-260. Academic Press (1964)

34. Winter, A., K. Ek \& U.-B. Anderssen: Analytical electrofocusing in thin layers of polyacrylamide gels. LKB application note 250 . 